ITEJ Juli-2020, Volume 5 Nomor 1 Page 1 - 13

ITEJ

Information Technology Engineering Journals eISSN : 2548-2157

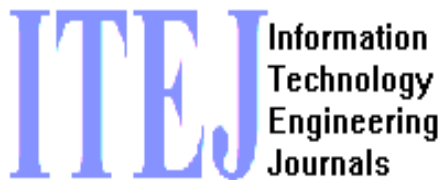

Url : https://syekhnurjati.ac.id/journal/index.php/itej

Email : itej@syekhnurjati.ac.id

\title{
A Survey : Application of Big Data in the Travel and Tourism Industry
}

\author{
Putri Previa Yanti \\ Sekolah Teknik Elektro dan Informatika \\ Institut Teknologi Bandung \\ Bandung, Indonesia \\ putriprevia@students.itb.ac.id
}

\begin{abstract}
The development of information technology has increased the travel and tourism industry. The travel and tourism data available in many sources such as telephone, social media, sensor system on internet of things, and others. The application of big data has great potential in the development of the travel and tourism industry. Big data can take advantage of new things in making the right decisions and seeing opportunities in doing better business. This paper provides a survey that discusses about big data in travel and tourism industry. Big data is used to ticket price and demand prediction. In addition, big data is also used to build a tourism plans and recommender system with personalized and adaptive method. Combination of using internet of things and big data can help industry to pricing their product. The result of this study is some of implementation of big data in travel and tourism industry. We conclude that big data can be used to explore new things in making the right decisions, seeing opportunities more observant, and doing business more efficiently.
\end{abstract}

Keywords - big data, travel industry, tourism, survey

\section{Pendahuluan}

Perkembangan era digital dalam beberapa tahun terakhir telah mengubah berbagai aspek kehidupan masyarakat. Era digital mendorong manusia untuk bertransformasi yang terus mewabah ke berbagai sektor. Kemampuan manusia untuk mengembangkan teknologi digital seolah tidak pernah berujung. Berbagai teknologi tak hentinya memanjakan dan memudahkan kehidupan manusia. Mulai dari kemudahan berkomunikasi, akses informasi, bisnis melalui aplikasi, hingga melakukan transaksi perbankan dirasakan seluruh lapisan masyarakat. Transformasi digital juga turut mempengaruhi industri dalam melakukan bisnisnya. Beberapa industri yang gencar melakukan transformasi digital adalah jasa keuangan seperti perbankan dan asuransi, industri minyak dan gas (migas), retail, manufaktur, transportasi dan travel, 
Industri travel atau perjalanan memiliki cakupan yang cukup luas. Pada awalnya, industri ini muncul untuk mendukung kebutuhan bisnis dan terus berkembang hingga saat ini menjadi industri yang cukup menjanjikan dengan pangsa pasar yang terus berkembang. Komponen utama industri ini adalah moda transportasi dan akomodasi.

Di masa lalu industri ini dilakukan dengan sistem agen yang menyediakan komponen tersebut, namun konsumen yang didominasi oleh pelaku bisnis menuntut industri ini beralih ke digital karena harus menyesuaikan regulasi yang berlaku dalam proses bisnisnya. Misalnya, aturan sebuah perusahaan untuk melakukan pembayaran berjangka atas perjalanan bisnis untuk mencegah penanganan yang terlalu banyak oleh agen. Perubahan sistem ini mengakibatkan pelaku industri travel beralih menggunakan teknologi informasi dengan menyediakan langsung sistem tersebut maupun melakukan bisnisnya melalui online travel agent (OTA). Akibatnya, persaingan antar pelaku industri menjadi terbuka.

Perkembangan teknologi informasi dan ilmu pengetahuan sangat berpengaruh pada industri travel dan pariwisata. Industri ini dapat memanfaatkan artificial intelligence, big data, virtual reallity, internet of things, dan berbagai teknologi lainnya dalam mendukung bisnisnya. Pemanfaatan big data mampu melakukan prediksi terhadap harga tiket maskapai dan jumlah permintaan penerbangan [1]. Selain itu, big data juga dapat digunakan untuk memprediksi perilaku penumpang maskapai penerbangan dalam melakukan perjalanannya [2]. Penggunaan internet of things juga dapat mendukung industri travel untuk memaksimalkan keuntungan yang diperoleh [3]. Big data dalam industri travel dan pariwisata juga dapat digunakan untuk membangun model perencanaan perjalanan wisata yang sesuai dengan penggunanya [4].

Data pada industri travel dan pariwisata tersedia dari berbagai sumber seperti data dari telepon, media sosial, sistem sensor, dan berbagai bidang lainnya. Analisa data tersebut dapat membantu menemukan pola dan informasi bisnis baru yang dapat dilakukan dengan lebih efektif dan akurat.

Big data pada industri ini memiliki banyak potensi dalam menggali kebutuhan pengguna dan nilai-nilai kepuasannya sehingga meningkatkan kemampuan bisnis bidang pariwisata dan mewujudkan smart tourism [5]. Big data dapat mencatat aktivitas dan perilaku pengguna dalam melakukan perjalanannya. Pengguna dapat dilacak secara digital melalui penggunaan telepon selular sehingga data perjalanan setiap pelanggan dapat tercatat. Dalam big data, data ini dapat digunakan untuk mengeksplorasi hal-hal baru dalam pengambilan keputusan yang tepat, melihat peluang secara lebih jeli, dan menjalankan bisnis secara lebih efisien [6].

Dalam makalah ini, dilakukan survei terhadap penerapan big data pada industri travel. Survei ini menghasilkan adanya penerapan big data dalam proses penetapan harga pada maskapai penerbangan [1], melakukan prediksi perilaku penumpang perjalanan udara [2], penetapan harga menggunakan data yang diperoleh dari IoT [3], dan membangun model perencanaan perjalanan wisata [4].

Makalah ini terdiri dari empat bagian. Pada bagian I. Pendahuluan telah dibahas latar belakang dan pentingnya menerapkan big data pada industri travel dan pariwisata. Pada bagian II. Survey akan dibahas survei yang dilakukan terhadap jurnal dan tulisan ilmiah yang terkait dengan big data pada industri travel dan pariwisata. Bagian III. Hasil dan Pembahasan akan membahas pembahasan terhadap survei yang dilakukan pada bagian sebelumnya. Pada bagian IV. Kesimpulan akan dibahas kesimpulan yang bisa diambil dari survei yang telah dilakukan dan peluang penelitian berikutnya. 


\section{SURVEI}

\section{A. Harga Dinamis pada Maskapai Penerbangan}

Pesawat merupakan salah satu moda transportasi yang menjadi komponen utama dalam industri travel. Moda transportasi ini tidak hanya digunakan dalam perjalanan bisnis namun juga dalam perjalanan wisata. Harga tiket pesawat yang mulai turun dan bersaing dengan moda transportasi lainnya membuat jumlah penumpang pesawat terus meningkat.

Harga tiket pesawat sangat bervariasi secara dinamis dan signifikan untuk penerbangan yang sama bahkan untuk bangku yang bersebelahan [7]. Harga dinamis menjadi salah satu strategi dalam penetapan harga yang paling umum yang diterapkan oleh industri penerbangan. Pelanggan tiket pesawat mencari tiket dengan harga yang rendah, sedangkan perusahaan maskapai penerbangan selalu mencoba meningkatkan pendapatannya dan memaksimalkan keuntungannya. Jumlah kursi yang tersedia terkadang tidak sesuai dengan permintaan pelanggan yang mengakibatkan pelanggan membayar lebih mahal atau perusahaan maskapai kehilangan pendapatannya.

Gambar 1 menunjukan harga dinamis pada tiket pesawat yang berhubungan dengan tujuan pelanggan dan perusahaan maskapai penerbangan [1]. Dalam menentukan harga, maskapai akan melihat data permintaan pasar terhadap tiket penerbangan, pelanggan yang akan membayar tiket dengan harga lebih, kemudian menentukan harga tiket yang optimal. Sedangkan pelanggan akan melihat waktu yang tepat untuk membeli tiket dengan harga murah dan berapa harga minimum yang dapat diperolehnya.

Maskapai penerbangan perlu mempertimbangan faktor internal dan faktor eksternal seperti perubahan permintaan, promosi yang dilakukan kompetitor, kemampuan pelanggan dalam membeli tiket, ketersediaan kursi, dan lain sebagainya untuk menyesuaikan harga tiket. Maskapai juga perlu memprediksi faktor tersebut untuk menerapkan skema harga dinamis untuk meningkatkan keuntungannya. Sementara itu, pelanggan perlu memprediksi harga tiket untuk memperoleh tiket yengan harga yang lebih murah.

Berbagai macam teknik pemodelan telah diterapkan menentukan harga tiket dan memprediksi perminataan. Teknik pemodelan ini dapat dikelompokan menjadi tiga kategori yaitu teknik pengujian hipotesis sederhana dan regresi, berbagai jenis teknik machine learning, dan ensamble learning [8].

\section{1) Prediksi Waktu Pembelian Tiket yang Optimal}

Banyak penelitian yang telah dilakukan untuk membuat model prediksi waktu pembelian tiket pesawat yang optimal. Penggunaan 12.000 data harga tiket dilakukan pada [7] yang dikumpulkan dalam 41 hari dengan menggunakan fitur nomor penerbangan, lama pemesanan hingga waktu keberangkatan, harga saat ini, maskapai, dan rutenya. Data ini diolah menggunakan teknik komputasional rule learning (Ripper), Q-learning, metode time series, dan kombinasinya. Hasilnya menunjukan penumpang dapat berhemat sebanyak $61,8 \%$.

Prediksi menggunakan big data lainnya dilakukan dengan mengumpulkan data sejak 60 hari menjelang keberangkatan untuk satu rute [9] dan tujuh rute [10]. Fitur yang diambil adalah jumlah hari sebelum keberangkatan, harga minimum, harga rata-rata. Menggunakan teknik PLS regression, decision tree, dan nu-SRV ridge regression dihasilkan 75,3\% [9] dan $69 \%$ [10] penghematan dalam pembelian tiket.

Penelitian lainnya menggunakan data yang dikumpulkan selama 28 hari untuk 6 rute penerbangan dari 9 maskapai [11]. Data ini juga mencakup perjalanan pulang pergi selama 3, 7, dan 14 hari. Fitur yang digunakan adalah bandar udara keberangkatan dan kedatangan, tanggal keberangkatan dan kembali, maskapai, hari dalam minggu, bulan, dan tahun tersebut, 
serta permintaan. Data diolah menggunakan teknik pemrosesan awal marked point processes (MPP), clustering dan klasifikasi, serta analisa statistik.

\section{2) Prediksi Harga Tiket Pesawat}

Berbagai penelitian dilakukan untuk memprediksi harga tiket minimal. Prediksi harga tiket minimum dapat dilakukan menggunakan fitur harga pada rencana perjalanan yang sama, harga pada rencana perjalanan saat ini sebelum hari target, harga rencana perjalanan pada hari yang sama di minggu dan bulan yang berbeda [12]. Data dikumpulkan selama lebih dari tiga bulan untuk lima rute penerbangan internasional dan menggunakan teknik komputasi ensemble-nased learning algorithm yang dimodifikasi.

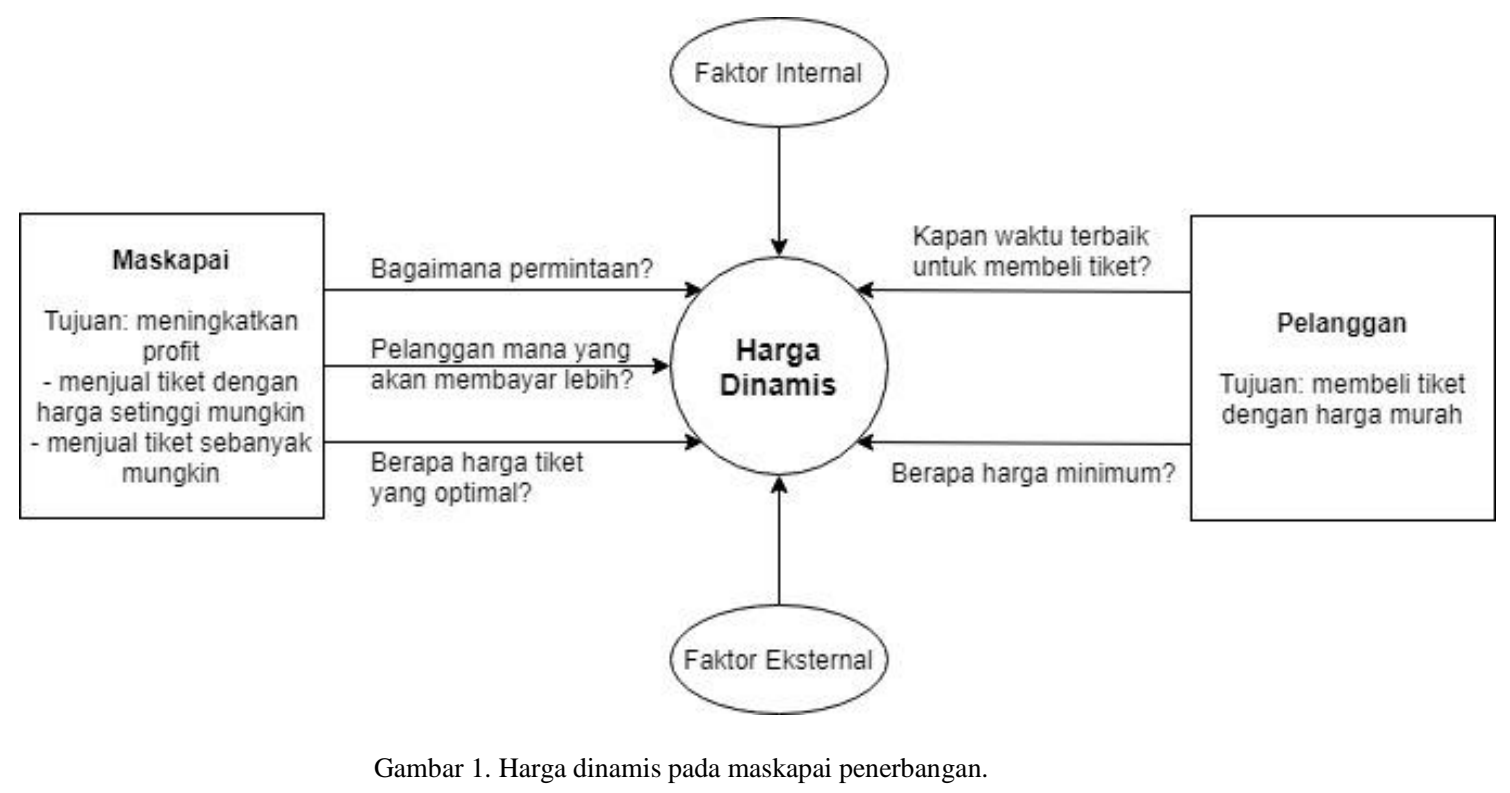

Penelitian lainnya dilakukan untuk memprediksi harga tiket minimum sebelum tanggal keberangkatan [13][14]. Fitur yang digunakan pada [13] terdiri dari harga historis tiket, hari libur atau tidak pada tanggal keberangkatan, dan jumlah hari sebelum keberangkatan. Data ini terdiri dari 19 rute yang berbeda selama periode 92 hari. Model dihasilkan dari menggabungkan beberapa teknik seperti k-nearest neighbors, random forest, dan bayesian. Pada [14], teknik komputasi yang digunakan adalah linear quantile yang digabung dengan model regresi menggunakan data 2.271 penerbangan dengan jumlah 126.412 records untuk sebuah rute yang dikumpulkan sejak 60 hari sebelum keberangkatan. Fitur yang digunakan adalah harga, tanggal keberangkatan, tanggal observasi, jumlah hari sebelum keberangkatan dan hari pada minggu itu (weekday atau weekend).

\section{3) Prediksi Permintaan Tiket Pesawat}

Permintaan pada industri travel cukup tinggi. Perkembangan teknologi mengakibatkan permintaan akan moda transportasi maupun akomodasi pada industri travel terus meningkat. Hal ini sejalan dengan perubahan industri travel yang pada awalnya lebih banyak melayani perjalanan bisnis hingga terus berkembang menjadi perjalanan wisata.

Penelitian tentang prediksi permintaan tiket pesawat yang dilakukan [15] menggunakan data panggilan customer selama tiga tahun, penjualan tiket, dan data pencarian dari kata kunci "Ticket" dan "TaobaoTrip". Teknik yang digunakan adalah neural networks dan support regression, namun dataset yang digunakan masih terbatas.

Fitur yang mempengaruhi permintaan tiket pesawat diantaranya harga tiket, jumlah penerbangan yang dilayani oleh maskapai, kinerja maskapai (waktu keterlambatan, rasio keterlambatan, rasio pembatalan, dan lainnya), ukuran pesawat, jumlah kursi, harga rata-rata, 
pendapatan populasi manusia, customer price index (CPI), jumlah keberangkatan per hari dalam satu minggu, jumlah pemesanan, promosi kompetitor [1]. Fitur gender dan informasi penerbangan seperti maskapai, bandar udara asal dan tujuan mempengaruhi permintaan untuk prediksi permintaan penumpang pesawat yang dipersonalisasi [1].

\section{4) Diskriminasi Harga}

Setiap penumpang pada pesawat sering mengalami diskriminasi harga. Diskriminasi harga yang dimaksud adalah adanya perbedaan harga kursi yang dipesan oleh seseorang dengan penumpang lainnya. Hal ini terjadi karena kebijakan maskapai penerbangan yang berlaku untuk pembelian tiket pada waktu tertentu maupun untuk waktu perjalanan tertentu. Hari pada minggu perjalanan, pembatasan tiket, karakteristik permintaan untuk penerbangan tersebut, jumlah hari setelah pembelian tiket mempengaruhi diskriminasi harga yang dialami oleh seorang pelanggan [1]. Data harga, pencarian yang dilakukan pelanggan, dan peluang mereka untuk melakukan penerbangan dapat digunakan untuk menentukan diskriminasi harga [16].

Sebanyak 1000 data penerbangan domestik di Amerika Serikat sejak 90 hari sebelum keberangkatan digunakan untuk menganalisa apakah hari mempengaruhi diskriminasi harga yang terjadi [17]. Fitur yang digunakan adalah hari dalam seminggu, hari dalam minggu perjalanan, pembatasan tiket, karakteristik permintaan pada penerbangan, dan jumlah hari setelah tiket dibeli. Data ini diolah menggunakan teknik regresi dan menghasilkan bahwa biaya tiket 5\% lebih rendah ketika dibeli pada saat akhir minggu. Hal ini hanya berlaku untuk penerbangan domestik dan menggunakan dataset dengan fitur yang terbatas.

\section{B. Prediksi Perilaku Penumpang}

Mobilitas manusia menjadi salah satu bidang penelitian yang menarik dilakukan. Perilaku mobilitas manusia dalam perjalanan darat cenderung lebih mudah dilakukan daripada mobilitas manusia yang melakukan perjalanan udara. Perilaku penumpang perjalanan udara dapat memberikan informasi karakteristik suatu kota, perencanaan bandar udara, perencanaan transportasi lokal, bisnis pariwisata, dan lain sebagainya.

Model prediksi perilaku penumpang perjalanan udara dapat dibuat menggunakan data passanger name reccord (PNR) yang dibuat anonim [2]. Model ini menghasilkan kecenderungan seseorang dalam memilih perjalanan pribadinya dan memprediksi permintaan penumpang melalui metode personalisasi yang menggunakan data karakteristik perilakunya. Karakteristik perilaku penumpang ini meliputi loyalitas penumpang, rute yang sering digunakan oleh penumpang, rute yang paling banyak peminat, maskapai yang digunakan penumpang. Model prediksi ini juga dapat memfasilitasi pemasaran maskapai penerbangan hingga melakukan analisa mobilitas manusia dan hubungan antar kota. Selain itu, model ini dapat membantu mengkaji berbagai permasalahan sosial ekonomi yang terkait dengan urbanisasi dan peradaban modern [2].

Kemajuan teknologi telah mengubah cara menghasilkan informasi oleh orang-orang yang terlibat dalam sebuah perjalanan. Mereka dapat mengakses infomasi dan menghasilkan konten sendri dari sudut pandang dan pengalaman masing-masing [18]. Konten tersebut dapat dibagikan melalui media sosial dan menjadi sumber informasi yang penting. Perilaku ini dapat mempengaruhi reputasi dan kinerja suatu penyedia jasa perjalanan maupun tempat wisata.

Perilaku membagikan informasi wisata melalui media sosial ini dapat digunakan untuk melakukan analisa sentimen yang muncul dengan tujuan menguji hubungan semantik makna ulasan yang dibagikan [18]. Volume data ini dapat berukuran sangat besar karena diambil 
dari sosial media dan memiliki kecepatan perubahan yang tinggi sehingga data yang dimiliki menjadi kompleks.

Model analisa sentimen dirancang berorientasi pada aspek implisit yang ada dalam ulasan untuk mengembangkan hipotesis baru, misalnya memahami hubungan antara kepuasan dan sentimen, kemudian memprediksi kepuasan turis dan menganalisa sentimen yang berorientasi pada teks. Dalam hal ini, big data dan deep learning dapat diterapkan unutk membantu menemukan dinamika baru dalam industri travel dan pariwisata [18].

\section{Pemanfaatan Internet of Things dalam Penetapan Harga}

Suatu perusahaan travel akan selalu berusaha meningkatkan pendapatannya dan memperbesar keuntungannya sehingga menjadikan konsumen sebagai target untuk mencapai tujuan tersebut. Perusahaan dapat memanfaatkan perangkat internet of things (IoT) dalam menentukan kebijakan penetapan harga [3]. Biasanya perusahaan akan menetapkan harga rendah, harga tinggi, dan harga kontingensi. IoT dapat menggantikan penetapan harga kontingensi dalam mengurangi ketidakpastian jumlah permintaan yang dapat merugikan perusahaan.

IoT digunakan untuk mengumpulkan data perilaku konsumen dan mengantisipasi dampak negatif dari ketidakpastian permintaan. Peningkatan penggunan IoT pada perusahaan juga bertujuan membentuk user experiences yang lebih baik. Hasilnya diharapkan dapat menjadi panduan bagi perusahaan dalam menentukan kebijakan yang sesuai untuk mendapatkan keuntungan yang tinggi dengan mempertimbangkan fitur konversi pelanggan yang lebih baik dan penilaian produk yang lebih tinggi. Tabel 1 berikut ini memperlihatkan temuan dan insight dari [3].

Perusahaan dapat menerapkan skema harga kontingensi dan memasangkannya dengan perangkat IoT yang sesuai dengan bisnis dan tujuannya. Harga kontingensi cenderung digunakan ketika perangkat IoT meningkatkan nilai produk. Dalam konteks tertentu, kebijakan menerapkan harga kontingensi dan IoT secara bersamaan dapat mengurangi ketidakpastian pembelian produk oleh pelanggan sehingga dapat meningkatkan keuntungan perusahaan [3]. 
Tabel 1. Temuan dan insight pemanfaatan IoT dalam penetapan harga.

\begin{tabular}{|c|c|c|}
\hline No & Kasus & Temuan dan insight \\
\hline 1 & Tanpa IoT & $\begin{array}{l}\text { Memilih harga kontingensi jika ada ketidakpastian pembelian } \\
\text { oleh pelanggan yang bernilai tinggi dan memilih harga tinggi } \\
\text { untuk kondisi sebaliknya }\end{array}$ \\
\hline 2 & $\begin{array}{l}\text { IoT } \\
\text { meningkatkan } \\
\text { target }\end{array}$ & $\begin{array}{l}\text { Menggunakan harga kontingensi dan IoT untuk mendapatkan } \\
\text { keuntungan jika ada ketidakpastian pembelian oleh pelanggan } \\
\text { yang bernilai tinggi. }\end{array}$ \\
\hline 3 & $\begin{array}{l}\text { Perusahaan } \\
\text { tidak dapat } \\
\text { meningkatkan } \\
\text { nilai produk }\end{array}$ & $\begin{array}{l}\text { Menggunakan harga kontingensi dan IoT untuk mendapatkan } \\
\text { keuntungan yang tinggi jika ada ketidakpastian pembelian oleh } \\
\text { konsumen yang bernilai tinggi. Harga kontingensi kecil } \\
\text { kemungkinan untuk menjadi skema penetapan harga yang } \\
\text { optimal karena harus memberikan subsidi yang lebih tinggi } \\
\text { kepada konsumen dengan nilai rendah. }\end{array}$ \\
\hline 4 & $\begin{array}{l}\text { Perusahaan } \\
\text { dapat } \\
\text { meningkatkan } \\
\text { nilai produk }\end{array}$ & $\begin{array}{l}\text { Menggunakan harga kontingensi dan IoT untuk menghasilkan } \\
\text { keuntungan yang lebih tinggi jika tidak yakin dengan } \\
\text { pembelian konsumen bernilai tinggi. Tetapkan harga yang lebih } \\
\text { tnggi untuk konsumen yang bernilai rendah dan tinggi dengan } \\
\text { kenaikan harga yang besar bagi konsumen bernilai tinggi. } \\
\text { Harga kontingensi cenderung menjadi skema penetapan harga } \\
\text { yang optimal karena investasi IoT lebih tinggi. }\end{array}$ \\
\hline
\end{tabular}

Skema penetapan harga pada Tabel 1 belum mempertimbangkan kondisi industri sebenarnya yang sangat kompleks sehingga perlu adanya penelitian yang mempertimbangkan ada banyak produsen dan banyak produk dalam industri. Oleh karena itu, penggunaan IoT dalam menentukan harga mungkin akan berbeda.

\section{Perencanaan Wisata}

Saat ini, industri travel tidak hanya fokus pada perjalanan bisnis seperti pada awal kemunculannya, namun mulai melayani perjalanan ibadah dan perjalanan wisata. Orangorang bepergian hingga ke seluruh dunia untuk mengunjungi tempat-tempat wisata yang berdampak pada ekonomi. Perencanaan wisata menjadi salah satu bidang yang diuntungkan dalam pariwisata dan dapat dilakukan oleh pelaku industri travel.

Tujuan perencanaan wisata adalah untuk meningkatkan kepuasan wisatawan yang ditunjukan dengan tingginya jumlah kunjungan. Wisatawan menginkan biaya perjalanan wisata yang rendah dengan kemudahan dan tidak menyita waktu untuk merencakannya. Membuat perencanaan untuk sebuah perjalanan wisata bukan suatu hal yang mudah. Perlu pengalaman dan pengetahuan mengenai hal tersebut. Oleh karena itu, sebuah model diusulkan untuk membuat perencanaan wisata menggunakan big data [4].

Model perencaan wisata yang diusulkan [4] dibuat berdasarkan permintaan pengguna dan mempertimbangan berbagai parameter penting, seperti anggaran wisata, lalu lintas wisata, cuaca kota tujuan wisata, dan waktu perjalanan wisata. Model ini menghasilkan berbagai rencana wisata yang terdiri dari data perjalanan, data pariwisata, profil wisata, data acara, dan data cuaca. Tujuan model ini adalah memilihkan tempat wisata ang menarik bagi pengguna dan mengatur waktu kunjungan berdasarkan infromasi yang diperoleh dari analisa big data perencanaan wisata. 


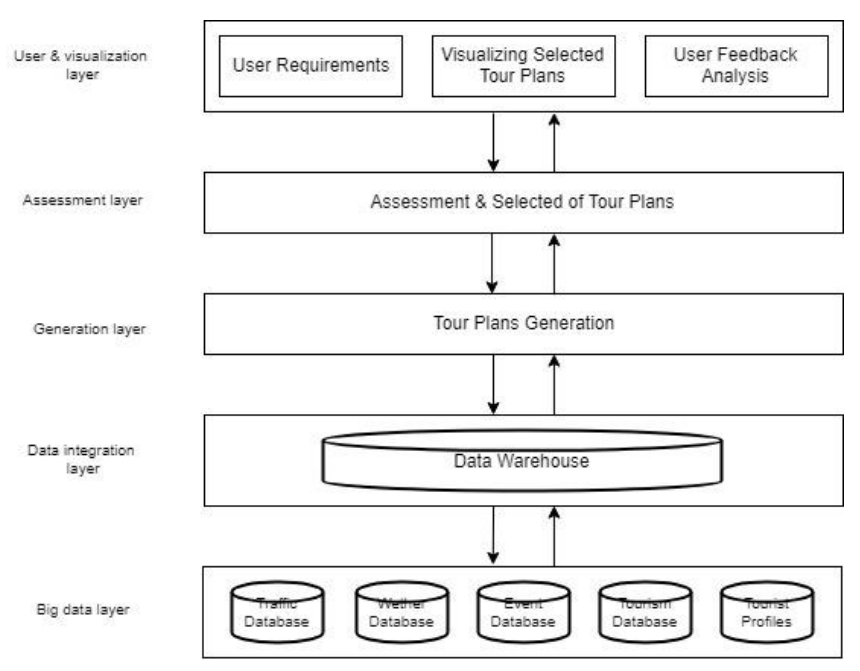

Gambar 2. Model perencanaan wisata menggunakan big data.

Gambar 2 menunjukan alur model perencanaan wisata menggunakan big data [4]. Berdasarkan kebutuhan pengguna dan big data perencanaan wisata, solusi optimal diperoleh menggunakan algoritma meta-heuristik. Algoritma ini tidak hanya mempertimbangkan kecenderungan pilihan pengguna seperti biaya yang dihabiskan untuk perjalanan wisata dan waktu perjalanan, tetapi juga mempertimbangkan pentingnya big data.

Model perencanaan wisata memerlukan kebutuhan pengguna yang terdiri dari prioritas dan kendala yang dihadapi pengguna. Beberapa database terintegrasi ke dalam data warehouse. Hasilnya berupa rencana perjalanan wisata. Kemudian dilakukan evaluasi dengan melakukan penilaian pada assessment layer. Rencana perjalanan yang dihasilkan diberikan kepada pengguna pada layer pertama. Selanjutnya, pengguna memberikan feedback pada profil wisata.

Penggunaan big data pada model perencanaan wisata menggunakan beberapa fitur, yaitu volume, keberagaman, kecepatan, keakuratan, dan nilai [4].

- Volume: Volume data diperoleh dari distribusi perjalanan wisata yang terjadi pada industri travel. Data ini dihasilkan setiap hari bahkan setiap jam. Jumlah data yang besar memungkinkan digunakan dalam perencanaan wisata.

- Keberagaman data: Teknologi menyediakan berbagai cara pengumpulan data dengan jenis data yang beragam, hanya sekitar $20 \%$ data wisata yang dimanfaatkan untuk meningkatkan industri travel.

- Kecepatan: Kecepatan dalam mengumpulkan data menjadi salah satu fitur penting dalam penggunaan big data untuk industri travel. Aspek penting dalam pengumpulan data antara lain penyimpanan dan analisa yang cepat, fitur tepat waktu karena beberapa data hanya bersifat sementara dan tidak bernilai lagi setelah periode tertentu, dan kecepatan untuk diambil dan disimpan.

- Keakuratan: Keakuratan data dalam big data menunjukan data yang bersifat tidak biasa dan mengganggu (noise). Akurasi pada data mempunyai tantangan yang besar dalam melakukan analisa data.

- Nilai: Nilai data wisata dapat dijelaskan dengan penerapannya pada industri travel. Pemasaran dalam industri ini yang ditambahkan dengan personalisasi menjadi peluang kuat yang bisa diperoleh dari big data. Analisa big data memberikan wawasan bisnis 
sebagai sumber inovasi pariwisata dan industri travel. Potensi yang tinggi ini tidak bisa diabaikan oleh pelaku industrinya.

\section{E. Penerapan Big Data pada Pariwisata}

Big data memungkinkan munculnya peluang baru dalam penelitian termasuk pariwisata. Penggunaan big data pada sektor pariwisata memungkinkan menggali pengetahuan baru seperti pemahanan mengenai perilaku wisatawan, mendeteksi kecenderungan dan kebutuhan untuk perkembangan pariwisata, prediksi permintaan tujuan pariwisata, rekomendasi hotel, restoran, maupun kegiatan secara real time sesuai preferensi masing-masing wisatawan.

Sebuah metode dikembangkan untuk mengidentifikasi dan memprediksi perilaku wisatawan, serta memprediksi permintaan wisatawan musiman [19]. Metode ini dikembangkan untuk keperluan pengembangan, pengelolaan, dan perencanaan pariwisata yang baik. Metode ini terdiri dari empat teknik sebagai berikut.

- Pemrosesan metadata tekstual untuk mengidentifikasi kata kunci yang menunjukan minat wisatawan pada saat mengambil gambar.

- Pengelompokan data geografis untuk mengidentifikasi lokasi populer dan diminati wisatawan.

- Identifikasi gambar yang representatif untuk mengidentifikasi subjek gambar yang paling sering muncul sesuai minat wisatawan sehingga dapat memberikan informasi mengenai pengalaman dan minat wisatawan.

- Pemodelan time series untuk memprediksi permintaan pariwisata di masa depan dan mengungkap pola perjalanan musiman untuk perencanaan dan pengambilan keputusan di masa depan.

Sebuah sistem rekomendasi yang adaptif dapat dikembangkan untuk membantu pelaku pariwisata dalam memahami selera wisatawan dan memberikan penawaran yang sesuai dan cocok bagi mereka [6]. Sistem rekomendasi ini berisi:

- Penawaran pariwisata dan konten yang direkomendasikan kepada pengguna sesuai segmentasi dan kebutuhannya.

- Informasi pengunjung akan disimpan untuk melacak dan menganalisa pendapat mereka dalam rangka meningkatkan customer experience.

- Kinerja industri pariwisata dapat dievaluasi menggunakan indikator statistik yang tersedia dalam bentuk dashboard untuk pengambilan keputusan dan penilaian dalam mencapai tujuan.

Sistem rekomendasi dan adaptif terdiri dari fungsi berikut ini [6].

- Pengumpulan data pariwisata yang tersedia pada website dan media sosial. Data ini disimpan dalam format yang kompatibel yang menyediakan metode dan standar intelligent access pada data.

- Melakukan analisa dan memilih informasi yang relevan untuk menargetkan turis potensial dengan lebih baik sehingga dikembangkan sistem analisa dan penelitian yang hanya menggunakan data dari kata kunci tertentu, seperti usia, kewarganegaraan, kecenderungan pribadi, kegiatan, dan lainnya. Data ini digunakan untuk menentukan profil pengguna sehingga turis tersebut dapat dikelompokan, misalnya kelompok petualang, anak muda, manula, turis budaya, turis bisnis, dan lainnya. 
- Menyediakan perjalanan yang dipersonalisasi dan disesuaikan dengan kecenderungan turis menggunakan sistem rekomendasi semantik dan adaptif.

- Pelacakan turis melalui akun media sosial seperti Twitter atau Facebook untuk menganalisa informasi terkait data tempat dan objek wisata serta pendapat mereka tentang wisata tersebut. Pendapat turis di ruang publik seperi media sosial sangat penting dalam bidang pariwisata karena pendapat seseorang dapat mempengaruhi orang lainnya.

- Menghasilkan dashboard pariwisata secara berkala yang dapat digunakan oleh pihak-pihak yang terlibat dalam bidang pariwisata seperti pemerintah, pengelola objek wisata, penyedia akomodasi, penyedia moda transportasi, dan lain sebagainya. Dashboard ini bertujuan memberikan visualisasi indikator dan statistik mengenai wilayah tersebut untuk membuat keputusan yang paling efektif dalam pengembangan pariwisata.

Gambar 3 menunjukan aksitektur sistem rekomendasi dan adaptif yang dihasilkan [6]. User model menggunakan pendekatan menengah untuk mendefinisikan profil pengguna dengan mendefinisikan model untuk stereotipe secara individual. Stereotipe turis dibagi ke dalam tujuh kelompok, yaitu turis muda, petualang, penyuka hiburan, turis manula, turis bisnis, turis budaya, dan turis internal. Domain model berisi data yang dikumpulkan dari media sosial, website, aplikasi seluler, geolokasi, perangkat IoT, dan lainnya. Kedua model ini membentuk hubungan dalam mendapatkan profil pengguna yang paling tepat melalui proses adaptasi. Setiap pengguna akan memiliki aturan asosiasi tertentu untuk mendapatkan profilnya.

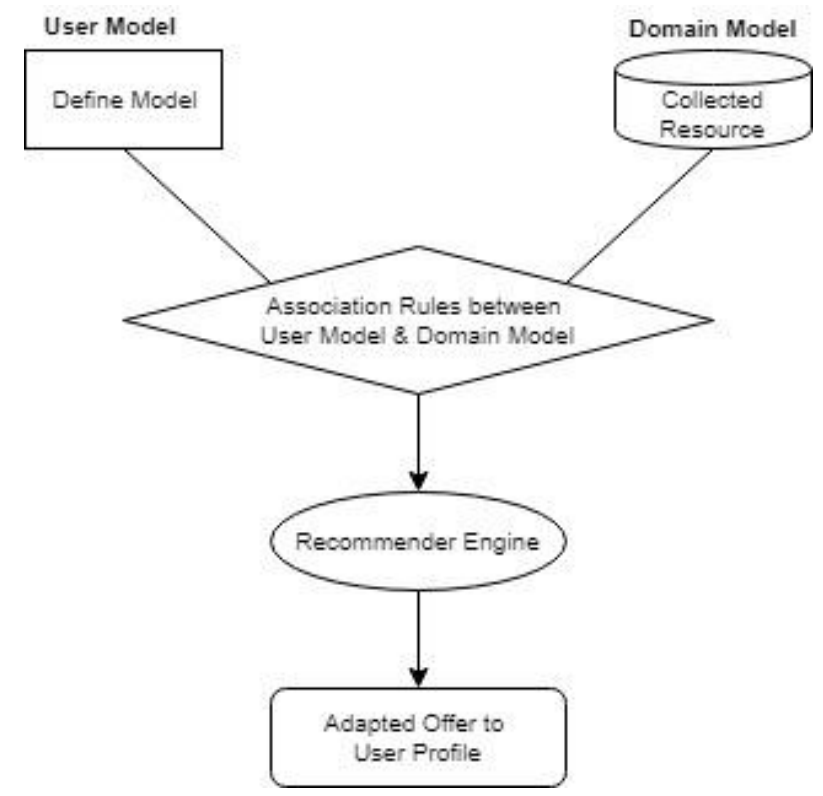

Gambar 3. Arsitektur sistem rekomendasi dan adaptif.

Dalam pengembangannya, sistem rekomendasi dapat menggunakan beberapa pendekatan. Pendekatan tersebut antara lain filter kolaboratif, filter berbasis konten atau hybrid filter yang mampu menghasilkan hasil yang menarik. Namun [6] menggunakan pendekatan sistem rekomendasi berbasis utility karena sumber data dan informasi mengenai pengguna tersebar di berbagai tempat, bisa dari pengguna langsung maupun dari media sosial miliknya. Sistem rekomendasi berbasis utility merupakan sistem rekomendasi berbasis onlotogi dengan metode filter kolaboratif berbasis media sosial. 


\section{HASIL DAN PEMBAHASAN}

Survei yang dibahas pada bagian sebelumnya membahas penerapan big data pada industri travel dan pariwisata. Big data menyediakan data pelaku industri ini baik sebagai menyedia maupun konsumen dalam industri. Data meliputi data historis yang dimiliki penyedia produk dalam industri, data perilaku konsumen travel dan pariwisata, hingga ulasan-ulasan yang tersedia pada media sosial dan situs web.

Big data digunakan untuk melakukan prediksi harga dinamis pada maskapai penerbangan. Harga dinamis muncul akibat perbedaan harga tiket setiap penumpang pesawat bahkan untuk kursi yang bersebelahan dalam satu penerbangan yang sama. Harga dinamis ini bisa ditinjau dari dua sisi, yaitu sisi penumpang dan sisi maskapai. Penumpang menginginkan harga tiket yang terendah yang bisa didapatkan sedangkan maskapai menginginkan keuntungan yang besar dalam bisnisnya.

Dari sisi penumpang, big data dapat digunakan untuk melakukan prediksi terhadap harga tiket pesawat dan kapan waktu membeli tiket yang tepat untuk mendapatkan harga tiket yang rendah. Model-model yang dibangun untuk memprediksi kapan waktu membeli tiket yang tepat menggunakan data yang diambil dalam rentang waktu tertentu mulai dari 7 hingga 60 hari dengan berbagai rute dan maskapai. Fitur-fitur yang dapat digunakan untuk membuat model prediksi tersebut terdiri dari nomor penerbangan, durasi penerbangan, harga saat ini, harga minimum, harga rata-rata, maskapai, harga historis, rute, lama hari sebelum keberangkatan, kota keberangkatan, kota tujuan, tanggal keberangkatan, tanggal kepulangan, harga minyak dunia, jumlah pemberhentian, dan jumlah maskapai pesaing.

Beberapa fitur yang berhubungan dengan model prediksi harga tiket pesawat diantaranya harga pada perjalanan yang sama, harga sehari sebelum hari target, harga pada hari yang sama pada minggu sebelumnya, harga pada hari yang sama pada bulan sebelumnya, tanggal keberangkatan, dan jumlah hari sebelum keberangkatan. Selain itu, fitur maskapai, nomor penerbangan, tanggal pembelian tiket, tanggal keberangkatan, waktu keberangkatan, waktu tiba, kelas penerbangan, jumlah pemberhentian, bandar udara keberangkatan dan tujuan, serta tanggal tiba juga digunakan dalam membangun model prediksi.

Dari sisi maskapai penerbangan, big data dapat digunakan untuk membuat model prediksi permintaan tiket pesawat dan diskriminasi harga. Fitur yang berpengaruh terhadap permintaan tiket pesawat diantaranya harga tiket, jumlah penerbangan yang dilayani oleh maskapai, kinerja maskapai (waktu keterlambatan, rasio keterlambatan, rasio pembatalan, dan lainnya), ukuran pesawat, jumlah kursi, harga rata-rata, pendapatan populasi manusia, customer price index (CPI), jumlah keberangkatan per hari dalam satu minggu, jumlah pemesanan, promosi kompetitor, gender, dan informasi penerbangan seperti maskapai, bandar udara asal dan tujuan. Sedangkan fitur yang mempengaruhi diskriminasi harga antara lain hari pada minggu perjalanan, pembatasan tiket, karakteristik permintaan untuk penerbangan tersebut, jumlah hari setelah pembelian tiket, data harga, pencarian yang dilakukan pelanggan, dan peluang mereka untuk melakukan penerbangan.

Perangkat IoT dapat digunakan untuk mengumpulkan data perilaku konsumen pada industri travel dan pariwisata. Selanjutnya, data ini dapat digunakan untuk menetapkan harga sebuah produk. Berbagai skema harga diperoleh dengan penerapan IoT untuk mendukung bisnis pada industri travel dan pariwisata.

Big data juga dapat digunakan untuk memprediksi perilaku penumpang pada perjalanan darat, laut, maupun udara. Model prediksi ini dapat menggunakan data karakteristik seorang penumpang, seperti loyalitasnya terhadap moda transportasi yang digunakan, rute yang sering digunakan, dan rute yang paling diminati. Hal ini dapat menjadi peluang pemasaran bagi 
penyedia moda transportasi. Selain itu, perilaku penumpang ini juga dapat dikaji untuk mendapatkan pola urbanisasi dan pengaruhnya terhadap sosial ekonomi di suatu daerah.

Selain itu, data mengenai perjalanan seseorang juga dapat digunakan untuk membangun model dalam merencanakan perjalanan untuk bisnis, wisata, ibadah, dan lain sebagainya. Model perencanaan wisata dibangun dengan tujuan meningkatkan kepuasan wisatawan dengan cara mengelola pariwisata dengan lebih baik dan meningkatkan nilai jual objek wisata. Perencanaan wisata dapat membantu wisatawan memilih objek wisata yang akan dikunjunginya dengan waktu yang tepat berdasarkan kecenderungan wisatawan itu sendiri. Hal ini akan memberikan kepuasan bagi wisatawan.

Kepuasan seorang wisatawan dapat menjadi sumber data lainnya yang dapat digunakan dalam industri travel dan pariwisata. Perkembangan teknologi informasi mengakibatkan adanya pergeseran nilai dalam kehidupan manusia. Seseorang akan cenderung membagikan sesuatu yang menarik atau tidak baginya melalui media sosialnya. Ulasan pada media sosial ini dapat menjadi sumber data yang dapat ditampilkan dalam bentuk dashboard untuk pengembangan pariwisata. Sistem rekomendasi juga dapat dibangun dari penerapan big data pada industri travel dan pariwisata.

\section{KESIMPULAN}

Big data telah diterapkan dalam berbagai bidang pada industri travel dan pariwisata. Berbagai fitur data pada industri ini dapat digunakan untuk mengembangkan bisnis menjadi lebih baik. Big data dapat membantu melakukan prediksi harga tiket pesawat, kapan waktu yang tepat untuk membeli tiket pesawat, prediksi permintaan tiket pesawat, dan diskriminasi harga. Kolaborasi antara big data dan internet of things menghasilkan skema harga yang optimal yang dapat diterapkan oleh penyedia moda transportasi untuk memaksimalkan keuntungannya. Perilaku penumpang dan data ulasan yang diberikan wisatawan dapat digunakan untuk membangun model perencanaan perjalanan wisata dan sistem rekomendasi wisata.

Penerapan big data pada industri travel dan pariwisata dapat menggali hal-hal baru yang mendukung pengambilan keputusan secara tepat, melihat peluang, dan menjalankan bisnis secara efisien. Berdasarkan survei yang telah dilakukan, masih perlu adanya penelitian lebih lanjut menggunakan data yang lebih akurat dan menggambarkan populasi pelaku industri travel dan pariwisata. Selain itu, perlu penelitan yang mengikutsertakan data dan ulasan pada media sosial dan situs web mengenai moda transportasi dan akomodasi dalam membangun sistem rekomendasi dan perencanaan perjalanan wisata.

\section{DAFTAR PUSTAKA}

[1] J. A. Abdella, N. Zaki, K. Shuaib, dan F. Khan, "Airline Ticket Price and Demand Prediction: A survey," J. King Saud Univ. - Comput. Inf. Sci., no. xxxx, 2019.

[2] J. Liu, B. Liu, Y. Liu, H. Chen, L. Feng, H. Xiong, dan Y. Huang, "Personalized Air Travel Prediction," ACM Trans. Intell. Syst. Technol., vol. 9, no. 3, hal. 1-26, 2018.

[3] X. Zhang dan W. T. Yue, "Transformative value of the Internet of Things and pricing decisions," Electron. Commer. Res. Appl., vol. 34, no. January, 2019.

[4] M. B. Dezfouli, M. H. N. Shahraki, dan H. Zamani, "A Novel Tour Planning Model using Big Data," in 2018 International Conference on Artificial Intelligence and Data Processing (IDAP), 2018, hal. 1-6.

[5] H. Song dan H. Liu, "Predicting Tourist Demand Using Big Data," in Analytics in Smart Tourism Design: Concepts and Methods, Springer International Publishing, 2017, hal. 
13-29.

[6] O. Boulaalam, B. Aghoutane, D. El Ouadghiri, A. Moumen, dan M. L. Cheikh Malinine, "Proposal of a Big data System Based on the Recommendation and Profiling Techniques for an Intelligent Management of Moroccan Tourism," in Procedia Computer Science, 2018, vol. 134, no. 2017, hal. 346-351.

[7] O. Etzioni, C. A. Knoblock, M. Rey, dan A. Yates, "To Buy or Not to Buy: Mining Airfare Data to Minimize Ticket Purchase Price Categories and Subject Descriptors," in 9th ACM SIGKDD International Conference on Knowledge Discovery and Data Mining, 2003, hal. 119-128.

[8] J. A. Abdella, N. Zaki, dan K. Shuaib, "Automatic Detection of Airline Ticket Price and Demand: A review," in 2018 International Conference on Innovations in Information Technology (IIT), 2018, hal. 169-174.

[9] W. Groves dan M. L. Gini, "An agent for optimizing airline ticket purchasing.," in Proceedings of the International Conference on Autonomous Agents and Multi-agent Systems, 2013, no. May 2013, hal. 1341-1342.

[10] W. Groves dan M. Gini, "On Optimizing Airline Ticket Purchase Timing,” ACM Trans. Intell. Syst. Technol., vol. 7, no. 1, hal. 1-28, 2015.

[11] T. Wohlfarth, S. Clémencon, F. Roueff, dan X. Casellato, "A data-mining approach to travel price forecasting," in Proceedings - 10th International Conference on Machine Learning and Applications, ICMLA 2011, 2011, vol. 1, no. M, hal. 84-89.

[12] Y. Chen, J. Cao, S. Feng, dan Y. Tan, "An ensemble learning based approach for building airfare forecast service," in Proceedings - 2015 IEEE International Conference on Big Data, IEEE Big Data 2015, 2015, hal. 964-969.

[13]T. Liu, J. Cao, Y. Tan, dan Q. Xiao, "ACER: An adaptive context-aware ensemble regression model for airfare price prediction," in Proceedings of 2017 International Conference on Progress in Informatics and Computing, PIC 2017, 2017, hal. 312-317.

[14] T. Janssen, “A Linear Quantile Mixed Regression Model for Prediction of Airline Ticket Prices," Radboud University, 2014.

[15] H. Yuan, W. Xu, dan C. Yang, "A user behavior-based ticket sales prediction using data mining tools: An empirical study in an OTA company," in 11th International Conference on Service Systems and Service Management, ICSSSM 2014 - Proceeding, 2014, hal. 16.

[16]D. Liu, "A Model of Optimal Consumer Search and Price Discrimination in the Airline Industry," 2015, hal. 1-31.

[17] S. L. Puller dan L. M. Taylor, "Price discrimination by day-of-week of purchase: Evidence from the U.S. airline industry," J. Econ. Behav. Organ., vol. 84, no. 3, hal. 801-812, 2012.

[18] A. Alaei dan S. Becken, "Sentiment Analysis in Tourism : Capitalizing on Big Data," J. Travel Res., no. December, 2017.

[19] S. J. Miah, H. Q. Vu, J. Gammack, dan M. McGrath, "A Big Data Analytics Method for Tourist Behaviour Analysis," Inf. Manag., vol. 54, no. 6, hal. 771-785, 2017. 